\title{
PROVERBIAL EXPRESSIONS IN NEWSPAPERS \\ A STUDY IN ESTONIA, FINLAND, AND SLOVENIA
}

\section{LIISA GRANBOM-HERRANEN, SAŠA BABIČ, PIRET VOOLAID}

This article ${ }^{1}$ examines proverbs and proverbial expressions in contemporary newspaper contexts and in everyday use in three languages: Estonian, Finnish, and Slovenian. Print editions of the Estonian newspapers Postimees and Tartu Postimees, the Finnish newspapers Helsingin Sanomat, Salon Seudun Sanomat, and Perniönseudun Lehti, and the Slovenian newspaper Dnevnik were scanned for use of proverbial material during May 2013. From the reader's point of view, proverbs are understood to be both etic and emic concepts. The article discusses how to recognize contemporary proverbial units in this study in newspaper texts. The quantitative part of the study outlines proverbial expressions among newspaper genres and sections, and the location of proverbial expressions within textual units. The qualitative part of the analysis concerns distinctive national differences (use of proverbial expressions in horoscopes in Estonia, combined with TV programs in Finland and opinion pieces or letters to the editor in Slovenia) and focuses on them in a cultural context. The qualitative study highlights the most essential concentrations of proverbs. The differences are outlined in the sections focusing on country-specific features. Keywords: proverb, proverbial expression, colloquial language, media, newspaper
Avtorice preucujejo rabo pregovorov in pregovornih izrazov $v$ kontekstih sodobnih časopisov in v vsakdanji rabi v treh jezikih: estonskem, finskem in slovenskem. Pregledano je bilo gradivo $v$ tiskanih izdajah, objavljenih maja 2013: estonska časopisa Postimees in Tartu Postimees, finski ćasopisi Helsingin Sanomat, Salon Seudun Sanomat in Perniönseudun Lehti in slovenski časopis Dnevnik. Pregovori so bili zbrani in obravnavani z vidika bralca, zato sta upoštevana tako emični kakor etični vidik obravnave. Avtorice je zanimalo, kako prepoznati sodobne pregovorne enote v časopisnih besedilih. Kvantitativni del študije opisuje pregovorne izraze $v$ časopisnih žanrih in delih ter lokacijo pregovornih izrazov $v$ besedilnih enotah. Kvalitativni del analize se osredinja na mesta z največ pregovori ter obravnava nacionalne razlike (uporaba pregovornih izrazov $v$ horoskopih $v$ Estoniji, $v$ kombinaciji s televizijskimi programi na Finskem in $v$ mnenjih ali pismih uredniku $v$ Sloveniji) in poudarja njihov kulturni kontekst. Razlike so opisane v poglavjih o značilnostih treh držav.

Ključne besede: pregovor, pregovorni izrazi, pogovorni jezik, mediji, časopis

\section{INTRODUCTION}

The idea of a study combining newspapers with paremiology in the twenty-first century was proposed during discussions at the 2011 Colloquium on Proverbs in Tavira. The intent was to look at newspaper texts from a paremiologic point of view. This is how a

1 The Folklore Department at the Estonian Literary Museum made this project possible. The Estonian part of the project was supported by institutional research grant IUT22-5 from the Estonian Ministry of Education and Research. The Finnish part was supported by the University of Jyväskylä, the Finnish Academy, the University of Turku, and the Finnish Cultural Foundation's Varsinais-Suomi Regional Fund. The Slovenian part was supported by the ZRC SAZU Institute of Slovenian Ethnology, Ljubljana. 
joint study involving Estonia, Finland, and Slovenia ${ }^{2}$ (2012-2014) was initiated. The pilot study covered one week, and the results presented here focus on one month of newspapers in 2013. The newspapers are largely the same (one from Slovenia was omitted and one from Finland was added): the Estonian newspapers Postimees and Tartu Postimees (studied by Piret Voolaid), the Finnish newspapers Helsingin Sanomat, Salon Seudun Sanomat, and Perniönseudun Lehti (by Liisa Granbom-Herranen), and the Slovenian newspaper Dnevnik (by Saša Babič). ${ }^{3}$ Three of these are daily national papers, two are regional, and one is local.

The aim of the two-stage three-year project was to look at whether and how proverbs and proverbial expressions appear in newspapers in three countries and languages. The purpose of the study was to obtain up-to-date data about proverbs and proverbial expressions in contemporary newspapers in everyday use. Newspaper texts and proverbs as a part of everyday use were examined from the perspective of folklore paremiology. Each author of the article focused on newspapers published in her native language. ${ }^{4}$

The working hypotheses for the qualitative project were: 1) both similarities and special features in use and selection will be found across different languages and newspapers; 2) proverbs are more common in some locations (e.g., titles and endings) because they sum up the content of the newspaper text and are more common in some journalism genres (e.g., comments and columns) because these are a personal response to the world or national events and they contain more metaphorical expressions than reported news; and 3) new proverbial expressions are used in newspaper texts less than established proverbial expressions.

\section{PRIOR RESEARCH ON PROVERB USAGE IN NEWSPAPERS}

Interest in the combination of proverbs and proverbial expressions in newspaper texts has been topical for quite some time, and the use and occurrence of proverbs in media texts has previously been analyzed from various aspects. ${ }^{5}$ Regarding the three countries in the

2 See: $<$ http//www.folklore.ee/rl/fo/koostoo/prov_news.htm>. This colloquium took place in 2011, during the Fifth Interdisciplinary Colloquium of Proverbs. Initially, more researchers were involved, but only three countries (Estonia, Finland, and Slovenia) later submitted papers for the "newspaper group." The project involved perspectives on proverbial utterances in European newspapers. The proceedings of that colloquium include articles by Babič (2013), Granbom-Herranen (2013), Lauhakangas (2013), and Voolaid (2013). These articles present research carried out by individual researchers within a common framework: newspaper texts from one week in May, 2012. The articles were well received by the scholarly community and we were encouraged to analyze a longer period of time. Thus the project Proverbial Expressions in Newspapers started.

3 Abbreviations: $\mathrm{PM}=$ Postimees, TPM = Tartu Postimees, HS = Helsingin Sanomat, SSS = Salon Seudun Sanomat, $\mathrm{PsL}=$ Perniönseudun Lehti, DN = Dnevnik.

4 Each researcher is responsible for analysis of her part of the research material, including the translation of proverbial utterances and categorization of proverbial expressions.

5 See, for example, Lüthi 1970; Mieder 1973, 2008; Boškovič-Stulli 1980; Pilz 1991; Chlosta et al. 1993; Carson Williams 2009. 
current project, prior to the 2012 pilot studies (Babič 2013; Granbom-Herranen 2013; Lauhakangas 2013; Voolaid 2013), only Estonian media texts had been analyzed from the paremiologic point of view (Järv 1999; Krikmann 2005).

\section{HOW TO RECOGNIZE A PROVERB IN NEWSPAPER TEXT}

Many attempts have been made to define proverbs in both the international and smaller national context. Definitions have been constructed at contextual, structural, and syntactic levels. They have also been proposed for various purposes by linguists, paremiologists, and folklorists. Compared to other elements of figurative speech, spotting a proverb or kernel of proverbial utterances is possible for a researcher that is familiar with paremiologic studies. It is commonly agreed that a proverb is a generalizing sentence, but these utterances stand out from the text mass due to their specific structure (Voolaid 2013: 293) and most often they violate Paul Grice's (1975) cooperative principle in text (Granbom-Herranen 2014b). Proverb texts most often represent syntactic stereotypes or syntactic formulas intrinsic to traditional proverbs, which helps proverb recognition (Krikmann 1997: 52). Proverbs are full of ideas and phenomena that correspond to their context, and, in order to comprehend a proverb, a researcher needs certain background knowledge of the language and culture (Čubelić 1988). A proverb is a short folklore form with a relatively fixed structure that is common during the timeline of use. In any case, despite this seeming simplicity, it is impossible to give an all-inclusive definition. As Lauri Honko puts it, "It is not always necessary, or even possible, in the dynamic research tradition to define the key concepts exhaustively, for there must always be room for new connections" (Honko 1989: 14).

The most commonly highlighted characteristics of a proverb are that it is a short, independent statement in a relatively stable form of a whole compound or simple sentence, which is or has been familiar within a framework at a particular time and in a particular place. In our opinion, proverbs are an indispensable part of language, expressiveness, communication, and culture, which live and change with use. This is also one of the reasons why it is impossible to offer a final lasting formula or definition for what this lively and living language structure is (Babič 2015: 48-55). This conclusion is also confirmed by Risto Järv (2009: 244-245). Unlike Mieder (1993: 36) and Arora (1994: 4), Järv is convinced that it is obvious that users of proverbs cannot always identify proverbs or distinguish between proverbs and other proverbial expressions.

A proverb is an expression that is accepted as a part of daily language in a certain society, and it lives if it passes social censorship. It has to be a part of literary use before it is accepted into the dictionary of a certain language (Babič 2015: 54-55). Today, a significant part of everyday communication is conducted in written form. Old proverbs are found in new forms or combinations, especially in written texts. The connections may be quite extraordinary when compared with the standard proverbial interpretation. In addition, new 
proverbs are created based on old proverbs and old proverbs are transformed. Sometimes they are turned into parodies of the old tradition (Babič 2010: 154-161; Granbom-Herranen 2014a: 555-556, 2014b: 108). In this study, the focus in collecting units is on contemporary proverbial expressions, including proverbs, references to proverbs, ${ }^{6}$ Bible quotations and references to them, slogans, ${ }^{7}$ proverbial aphorisms, ${ }^{8}$ and citations, ${ }^{9}$ as well as references to other folklore genres ${ }^{10}$ that reference traditional proverbs or are used as a proverbial expression. We believe that only by including findings of all these proverbial forms can we obtain comprehensive data about the presence and positioning of paremiologic units in journalism texts. In this we follow Arvo Krikmann (1997: 52), who pointed out that in fact it is not an easy (or even possible) task to make a clear difference between proverbs, shortened proverbs, or references and allusions to them. One point where cultural knowledge is necessary has been identifying traditional proverbs, references to them, and one-time changes in proverbs as well as phrases based on or derived from traditional proverbs. This means that, when looking for proverbs in speech and speech-like text, it is necessary to weigh all proverbial expressions. The "paradox" of contemporary proverbs has been solved by including both new (modern) and old (traditional) proverbs under the term. The assumption is that the modern ones are the most paradox-bound because they are challenging to identify because it is not known what exactly is being looked for. If one just looks for proverbs, nothing new will be found. In this article, proverbs are not divided by their origin because all proverbs work in the same way (cf. Mieder 2014: 17).

\section{THEORIES THE STUDY IS BASED ON}

In this study, the significance of an utterance has some basic starting points. First, language is not understood only as an instrument of communication but, because it is linked to thought (Vygotski 1967), language use needs some context. Second, in order to be understood, an utterance should follow Grice's (1975) cooperative principle. Third, the theory central to analyzing the proverbs of Estonia, Finland, and Slovenia uses the idea of emic and etic proposed by Kenneth Pike and Marvin Harris (see Headland 1990). Etic-based definitions of proverbs are used by paremiologists and other researchers, and emic-based definitions of

6 Including proverb parodies (as defined in Krikmann 1985), or anti-proverbs (Litovkina and Mieder 2006).

7 A memorable motto or phrase used in a political, commercial, religious, or other context as a repetitive expression of an idea or purpose.

8 A proverbial aphorism is an authorial thought that contains life wisdom and has a structural form similar to that of a proverb.

9 Citations are direct quotations from different sources that people have accepted in their paremiological vocabulary. Although the author of a citation is well known, it is used in the function of proverb.

10 Such as riddles, fairy tales, and so on. 
proverbs are implicitly understood concepts in the vernacular but are not actually defined (Granbom-Herranen 2010b: 217). In everyday language, the emic definition of a proverb is more important than outsiders' etic definition. ${ }^{11}$ In any case, in contemporary use the concept "proverb" is most often understood to mean "proverb and proverbial expression" in both emic and etic language. On the one hand, this article leans toward the etic definition of the proverb and proverbial expressions because we exclude phrasemes, omens, and some superstitions that are parts of the emic definition. On the other hand, the article uses the emic definition with proverbs others than so-called traditional proverbs. This follows Arora's (1994: 22-23) idea that it is necessary to know the criteria by which people classify proverbs in emic language, even if these sayings cannot be considered proverbs in the etic sense, irrespective of their users' emic classification. If some genre definitions have lost their relevance over time, it is not only a question of the genre but also of the users of the genre systems (Ben-Amos 1976: 215). The proverb genre is a tool, not an end in itself, and the genre nevertheless frames research and the discipline.

To use a proverb is a small performance that has a target combined with the ongoing event and words used (Briggs 1988). This performance might be defined as a folklore moment, which consists of three levels: text, context, and texture (Babič 2014). ${ }^{12}$ Here, texts are the words that make up the proverb, texture is the way the proverbial statement is delivered, and the context includes all the circumstances that influence the choice of proverb as well as its articulation. The performer and audience must share some common background knowledge in order to be able to connect the proverbial message with the ongoing activity, while unavoidably there are audience members that are not capable of interpreting proverbs (Granbom-Herranen 2008: 184; Ferretti et al. 2007). Proverbs are suitable for short performances (folklore moments), for example, because of their form (shortness, rhythm), and a fitting proverb can sum up a discussion. The performance characteristics are retained when a folklore moment is moved to a new environment; for example, from speech to colloquial writing.

\section{NEWSPAPER TEXTS AS SOURCE MATERIAL}

Our study was based on a sample of newspapers published in May 2013. By the term newspaper, we mean here specifically what a subscriber would physically receive during that one month. As in the pilot study, we only looked at the printed versions of newspapers. One reason for this is that the Internet version is perpetually changing and is not publicly accessible in its entirety. The paper version includes a greater number of categories and

11 Pike's and Harris's points of view drastically differ on etic interpretations and their justification; they are very much in agreement regarding the emic ones (Headland 1990).

12 Similar to Alan Dundes's folklore event (1965: 20-32). 
texts within a category. The paper version is written and published for the general public, and in many cases edited (more than the online articles) for language (and proverb) usage. Moreover, in all three countries the printed version is available in many public places (e.g., libraries) and can be read by anyone at no cost. For purposes of reading, the paper newspaper is easier to handle than the version accessible on a computer, tablet, or mobile phone.

The newspapers for the study were chosen by national status in the country (national newspapers) and the local expertise of authors of this article (regional and local newspapers). Each language is represented by one national newspaper, and the Estonian and Finnish use of proverbial expressions was also inspected in regional and local newspapers. The newspapers Postimees, Helsingin Sanomat, and Dnevnik are national newspapers, Tartu Postimees and Salon Seudun Sanomat are regional newspapers, and the only local newspaper is Perniönseudun Lehti. The newspapers are printed in various sizes and fonts, but these differences are not significant. The month of newspapers corresponded to 624 (PM) and 336 (TPM) pages in the Estonian case; 2,752 (HS), 562 (SSS), and 64 (PsL) pages in the Finnish case; and 871 (DN) pages in the Slovenian case. There are also differences in how often they are published and how wide their circulation is, as described below. Because the study focused on how proverbs live in contemporary use, quantitative comparisons were not central, but were instead used as approximate information. Illustrative descriptive statistics are presented in the following paragraphs.

\section{ESTONIAN NEWSPAPERS}

The newspaper Postimees (The Postman) is the oldest Estonian daily newspaper still published, established on January 1st, 1857 by Johann Voldemar Jannsen. ${ }^{13}$ It was a cornerstone of the Estonian Age of Awakening (1860-1890), which took place under Tsar Alexander II. Karl August Hermann purchased the paper in 1886, and he began publishing Postimees in Tartu. In 1891, Postimees became Estonia's first daily newspaper. In 1896, the newspaper was purchased by Tartu intellectuals. Postimees has played an important role in educational and cultural development. Today the newspaper has over 242,000 readers and a daily circulation of 61,000 to 72,000 (the population of Estonia was about 1.3 million at the beginning of 2013). ${ }^{14}$ It has an editorial board in Tallinn and in Tartu. Postimees is published Monday to Saturday (except on legal holidays), with supplements for different target groups. In May 2013, one issue of the newspaper had twenty to twenty-eight pages. The Saturday supplement Postimees Arter has dedicated subsections. Most printed news in 2013 was also freely full-text accessible on the website ${ }^{15}$ and readers could submit (anonymous) comments.

\footnotetext{
13 The first newspaper published in Estonia and in Estonian was Tarto-maa rabva Näddali-Leht (Tartu Peasants' Weekly) in 1807.

$14<$ http://www.stat.ee/72509> (accessed February 20th, 2015).

$15<$ http://www.postimees.ee/>
} 


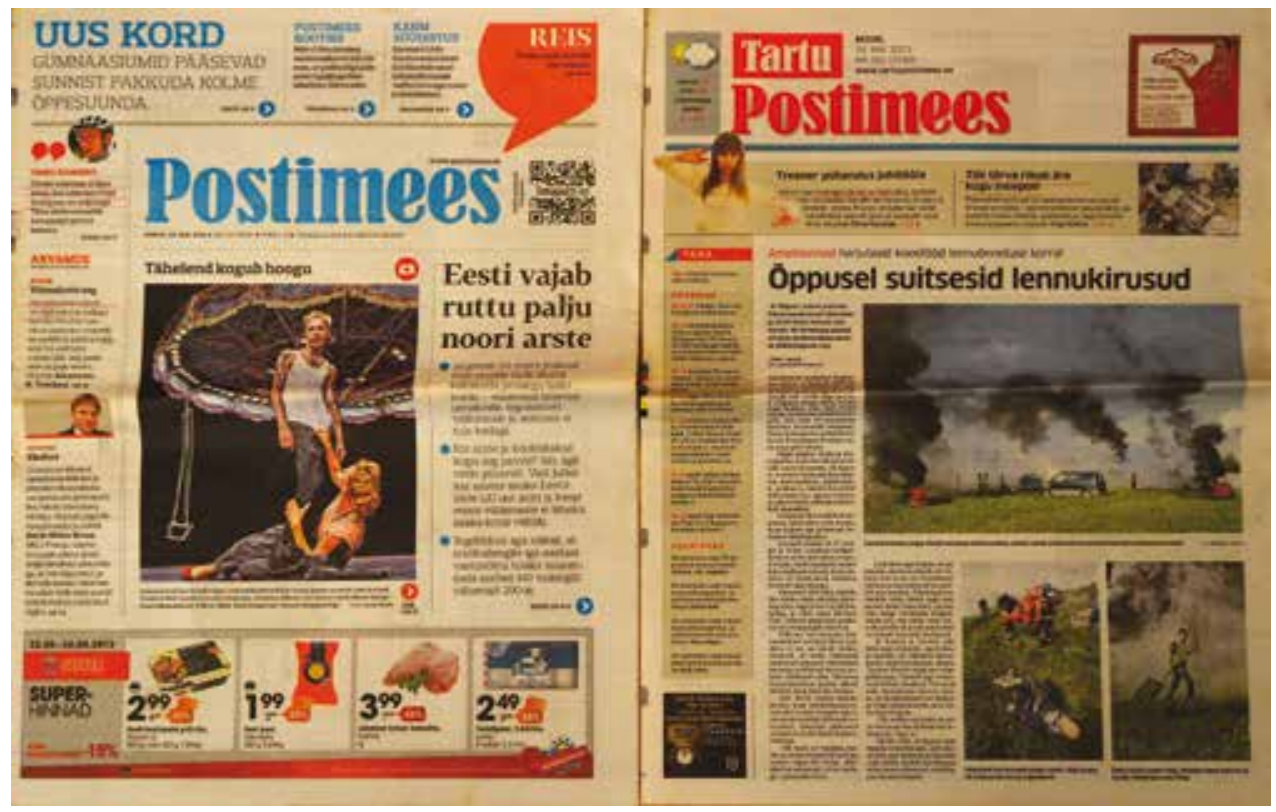

Figure 1. Front pages of Postimees and Tartu Postimees.

Five days per week, Postimees publishes regional editions for the largest towns in Estonia (Tartu Postimees has approximately sixteen pages per day). Tartu Postimees is the largest regional newspaper in Estonia and is published in the towns of Tartu and Otepää, as well as in Tartu and Jógeva counties. Tartu Postimees ${ }^{16}$ has 57,000 readers daily and its average circulation was 18,700 in $2013 .^{17}$

\section{FINNISH NEWSPAPERS}

Helsingin Sanomat (Helsinki Newspaper) is currently the largest subscription newspaper in Finland. It was founded in 1899, when Finland was still an autonomous Grand Duchy of Russia. The newspaper has always been published in Finnish and was originally called Päivälehti (Daily Paper) from 1889 to $1904 .{ }^{18}$ Today, it is published daily (except on the day after certain state holidays). In 2013, its circulation was about 355,000, with about 850,000 readers $^{19}$ (the population of Finland was about 5.5 million at the end of 2013). ${ }^{20}$

$16<$ http://tartu.postimees.ee/>

$17<$ http://eestimeedia.ee/ettevotted-ja-brandid/eesti-ettevotted/as-postimees>

18 The first newspaper published in Finland (when it was part of Sweden) was Åbo Tidningar (Turku News, 1771), published in Swedish. Today, the oldest newspaper in Finland, published since 1824, is Åbo Underrättelser (Turku Information), a Swedish-language newspaper (http://en.wikipedia.org/ wiki/Turku\#Media, March 28th, 2013).

19 <http://fi.wikipedia.org/wiki/Helsingin_Sanomat> (accessed October 18th, 2014).

$20<$ http://vrk.fi/default.aspx?site=4> (accessed November 10th, 2014). 
In May 2013, one issue of Helsingin Sanomat had sixty to 132 pages; the monthly supplement was eighty-eight pages.

Salon Seudun Sanomat (Salo District Newspaper) is a regional newspaper, published daily (except on the day after certain state holidays). The newspaper was established in 1919 and it has always been published in Finnish. In 2013, the daily circulation of the newspaper was about 20,000, with about 50,000 readers. ${ }^{21}$ In May 2013 the newspaper contained sixteen to twenty-eight pages, with topical daily sections taking up one to ten pages. Most of the readers live in Salo and its surroundings; Salo is a coastal town of about 54,500 in prosperous southwest Finland.

Perniönseudun Lehti (Perniö District Newspaper) is a local newspaper focusing on the southern Salo districts. The newspaper has always been published in Finnish (even when Finland was an autonomous Grand Duchy of Russia). From 1903 to 1944 it was published under the name Perniön Kuulutuksia (Perniö Announcement). At present, it appears once a week, on Thursdays. The circulation in 2013 was 4,428, with about 16,000 readers. ${ }^{22}$

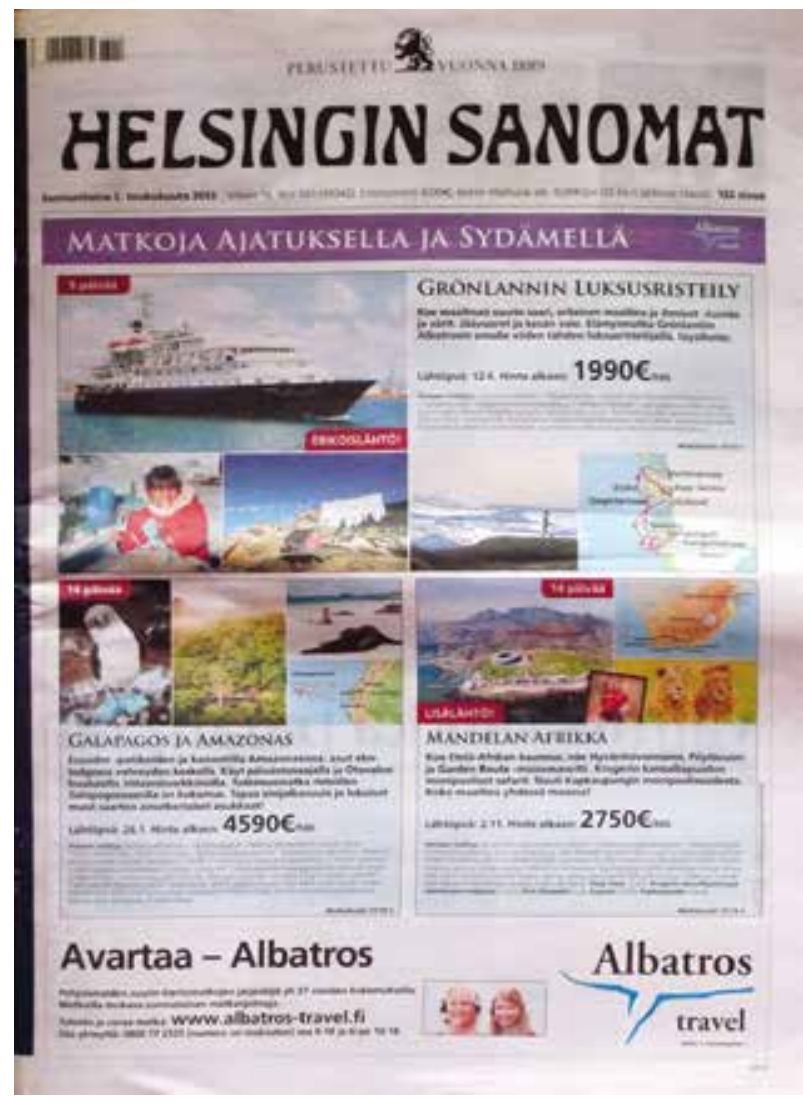

Figure 2:

Front page of Helsingin

Sanomat.

$21<$ http://mediaauditfinland.fi/english/> (accessed October 3rd, 2015).

22 Information emailed by the editor of Perniönseudun Lehti, September 3rd, 2014. 


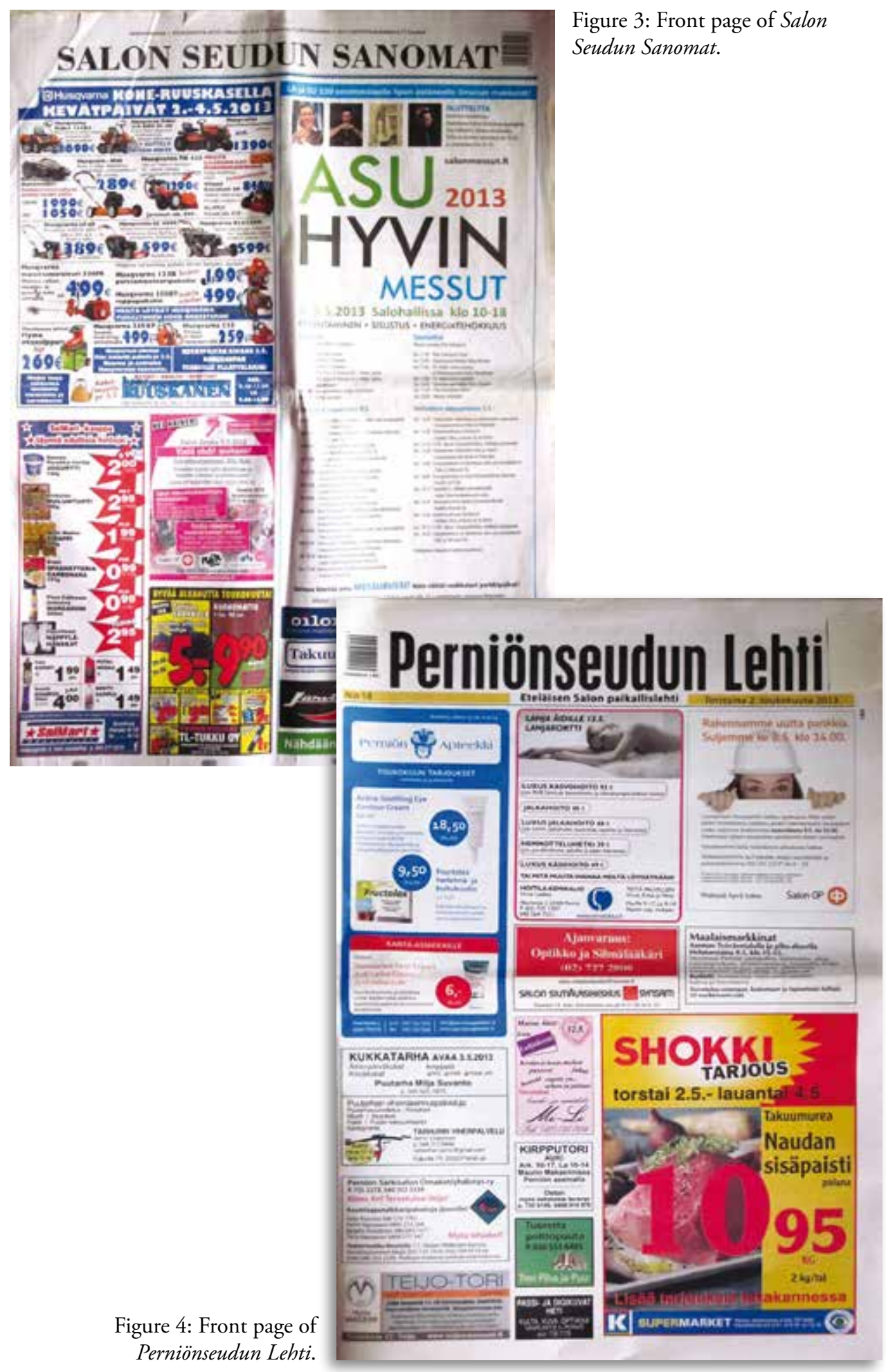




\section{SLOVENIAN NEWSPAPER ${ }^{23}$}

Dnevnik is one of several Slovenian national newspapers. The newspaper (established in 1951 ) is published from Monday to Saturday (except national holidays), with supplements for different target groups. One issue has thirty-three to thirty-six pages. Daily topics include domestic and international politics, economics, finance, business, culture, the police report, sports, and traffic. Apart from this, the weekly additions feature additional topics (e.g., health, entertainment, pop culture, fashion, and cars). Dnevnik is one of the most popular newspapers in Slovenia. ${ }^{24}$ It has the most subscribers in the central part of Slovenia, including its capital, Ljubljana. It is known as a left-wing newspaper. In the second quarter of 2013, Dnevnik had a circulation of 37,284 (the population of Slovenia was about two million at the beginning of 2013$)^{25}$ of which 26,785 were subscriptions. ${ }^{26}$

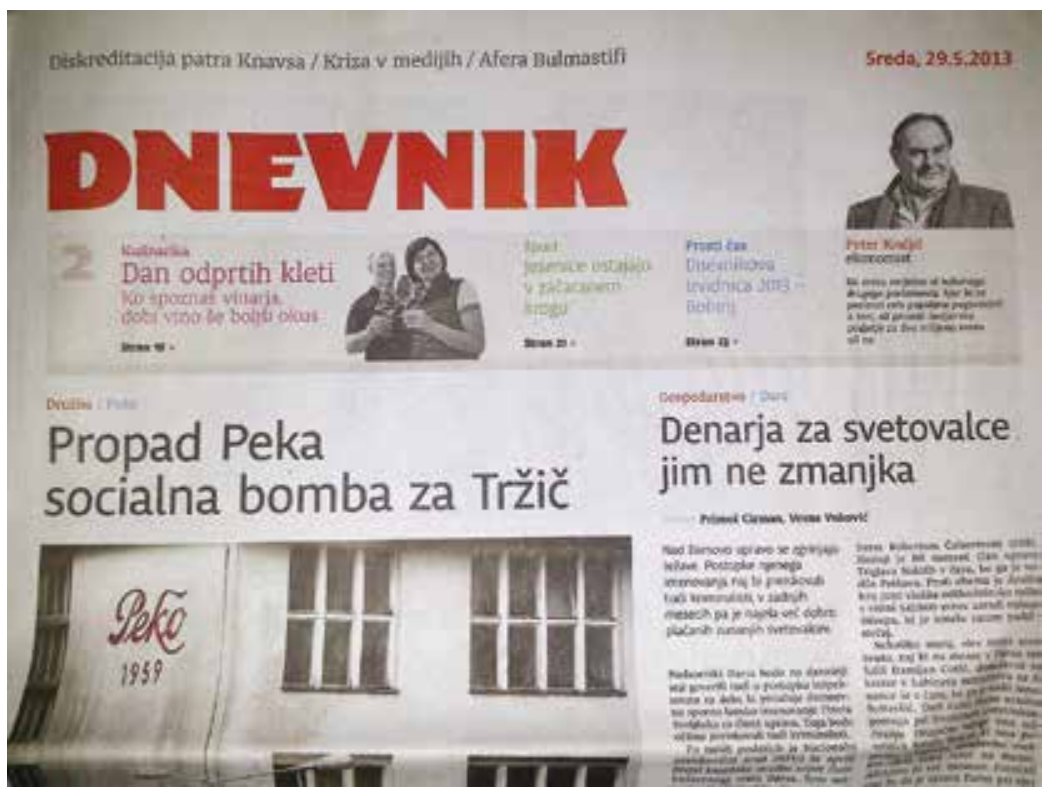

Figure 5: Front page of Dnevnik.

23 The first Slovenian newspaper published in Slovenia was Lublanske novice (Ljubljana News), established in 1797. Rubrics included announcements, obits, war news, and ethnographic, historical, and literary articles. Because of a lack of funding, it shut down by December, $1800<$ http://www.zgodovina.eu/mediji/izvor slovenskih_medijev.htm> (accessed August 15th, 2014). At that time, German was the official language in the Slovenian area, but the spoken language in the Slovenian area was Slovenian, later given the status as an official local language in 1811 during the Napoleonic years.

24 Another national newspaper is Delo. We chose Dnevnik as the newspaper with longest tradition.

$25<$ http://www.stat.si/eng/novica_prikazi.aspx?id=5454> (accessed February 20th, 2015).

$26<$ http://www.dnevnik.si/druzba-dnevnik/o-druzbi/zgodovina> (accessed February 20th, 2015); <http:// www.soz.si/> (accessed February 20th, 2015). 


\section{METHODS}

This study uses mixed methods, predominantly qualitative ones. The principal research method is content analysis, which is understood as a cluster of methods connected with empirical and theoretical methods. Content analysis is commonly used with existing text material (e.g., text published in newspapers) and it differs from discourse analysis, which concentrates on communication in written form, although the contact between the sender and receiver of a message is important (Granbom-Herranen 2010a, 2014a).

The study was conducted in four stages. During the first stage, we acquainted ourselves with the newspapers listed above in May, 2013. Proverbs in the newspapers were approached from the reader's point of view and they were detected while reading texts as newspaper readers. In practice, this means that we read the papers daily, the way all newspaper readers do. In the second stage, we defined the working concept of proverb in twenty-first-century layman's terms, as described above. Sentences or parts of sentences are the units we focused on. The third stage concerned identifying the proverbial utterances in the source texts. As mentioned above, there are various ways to define proverbs and also various ways to identify them. For identification purposes, we used Grice's “cooperative principle” (1975), proceeding from the fact that all proverbial expressions in some way violate Grice's cooperative principle (Granbom-Herranen 2014b). This was probably the most challenging stage. In this stage we identified and recorded all occurrences of any kind of proverbial expressions, including phrases and idioms. The units of content analysis consist of short folklore genres (see Table 2). Although the meaning of proverbs is not discussed in this article, we agree that proverbial units derive their meaning units ${ }^{27}$ from the context they appear in. The categorization was done in order to make potential cross-cultural similarities and differences visible. In this stage, many expressions were excluded; for example, phrases, idioms, and riddles. The focus is on expressions, and for all proverbial expressions included in further inspection the expression is connected with the basic form of the proverb that a modification or variation refers to. Some approximate statistics concerning the material and the number of units are presented in Table 1.

Table 1. Illustrative descriptive statistics of newspaper content analyzed from May 2013.

\begin{tabular}{|c|c|c|c|c|c|c|c|}
\hline & \multicolumn{2}{|c|}{ Estonian } & \multicolumn{3}{|c|}{ Finnish } & \multirow{2}{*}{$\begin{array}{c}\text { Slovenian } \\
\text { DN }\end{array}$} & \multirow[b]{2}{*}{ Total } \\
\hline & PM & TPM & HS & SSS & PsL & & \\
\hline Issues & 34 & 22 & 31 & 31 & 5 & 25 & 148 \\
\hline Pages & 624 & 336 & 2752 & 562 & 64 & 871 & 5209 \\
\hline Proverbial expressions ${ }^{28}$ & 481 & 81 & 560 & 375 & 8 & 36 & 1541 \\
\hline Proverbial expressions / page (average) & 0.77 & 0.24 & 0.20 & 0.67 & 0.13 & 0.04 & 0.30 \\
\hline Pages / proverbial expression (average) & 1.30 & 4.15 & 4.91 & 1.50 & 8.00 & 24.19 & 3.38 \\
\hline
\end{tabular}

27 "Meaning unit" in Elo and Kyngäs (2008: 109).

28 Proverbial units in language other than the one of the newspaper: PM 10; TPM 0; DN 1; HS 17; SSS 10; PsL 0. 
Stage four involved classification of the proverb material. As a part of content analysis, this started with quantitative specification. The results were collected for a table and followed by classification. Table 1 includes some statistics of the newspapers as a context for proverbs. All of the sections of newspapers are included, and this article does not discuss them in greater detail. The sections are unique depending on the way the newspaper is organized. Common quantitative units are categories of proverbial expressions (see Table 2).

The qualitative study is based on sufficient material and extensive analyses, and it is expected to use research methods that make it both repeatable and appreciable. The study will fulfill all of these criteria. Ethical issues as well as good academic practice were considered and the study was conducted based on published material.

\section{PROVERBIAL MATERIAL FOUND IN THE NEWSPAPERS}

\section{STATISTICS}

An illustrative overview of proverbial material selected for further study is presented in Table 2, showing the frequency of proverbial expressions in percent (traditional and modern proverbs as well as references to them, Bible quotations and references to them, slogans, aphorisms, and proverbial citations) in each newspaper. Providing a definition for what constitutes a traditional proverb and modern proverb was a challenge. ${ }^{29}$ However, once this was established, references to traditional proverbs were quite easy to spot. This might be one of the reasons why traditional proverbs and Bible quotations as well as references to them are so abundantly represented in the data. It is possible that modern proverbs were not as easy to observe and that some of them were therefore missed. Each member of this project worked with her own native language to minimize this possibility.

29 In the Estonian context, it was interesting to determine how many of the proverbs published during that period are listed in the registered type index in the publication Eesti vanasonad (Estonian proverbs I-IV, 1980-1988; Voolaid 2013). Inclusion in this index was also the criterion for a proverb to be traditional, not modern. Most Finnish proverb types from before the 1950s are included in three published collections: Nirvi and Hakulinen (1948), Kuusi (1953), and Laukkanen and Hakamies (1978). In the Finnish research tradition, the concept of the proverb has been advanced to coincide with the types and structures presented in these publications (Granbom-Herranen 2014a: 545). For the Slovenian cultural space, proverbs were already defined in the nineteenth century in Wilhelm Urbas's discussion (1869). Nevertheless, the criterion for differentiating traditional and modern proverbs is Fran Kocbek and Ivan Šašelj’s supplemented edition of the proverb collection from 1934: if a proverb is included in that collection, then it is treated as traditional proverb; if not, it is a modern proverb. 
Table 2. Short form genres in percent

\begin{tabular}{|c|c|c|c|c|c|c|c|}
\hline & \multicolumn{2}{|c|}{ Estonian } & \multicolumn{3}{|c|}{ Finnish } & \multirow{2}{*}{$\frac{\text { Slovenian }}{\mathrm{DN}}$} & \multirow[b]{2}{*}{ Total } \\
\hline & PM & TPM & HS & SSS & PsL & & \\
\hline Traditional proverb & 3.5 & 1.2 & 28.9 & 29.1 & 25.0 & 41.7 & 19.9 \\
\hline Reference to traditional proverb & 2.9 & 4.9 & 33.6 & 32.8 & 37.5 & 0.0 & 21.5 \\
\hline Modern proverb & 52.0 & 65.4 & 17.7 & 17.9 & 12.5 & 44.4 & 31.5 \\
\hline Reference to modern proverb & 0.8 & 0.0 & 6.6 & 3.2 & 12.5 & 0.0 & 3.5 \\
\hline Bible quotation & 0.8 & 1.2 & 4.6 & 11.5 & 12.5 & 2.8 & 4.9 \\
\hline Slogan & 12.7 & 11.1 & 3.6 & 2.1 & 0.0 & 0.0 & 6.4 \\
\hline Aphorism & 13.9 & 7.4 & 2.0 & 2.1 & 0.0 & 0.0 & 6.0 \\
\hline Paremiologic citation & 13.3 & 8.6 & 3.0 & 1.3 & 0.0 & 11.1 & 6.3 \\
\hline Total \% & 100 & 100 & 100 & 100 & 100 & 100 & 100 \\
\hline Total number & 481 & 81 & 560 & 375 & 8 & 36 & 1541 \\
\hline
\end{tabular}

\section{Estonia}

The majority of the proverbs and proverbial expressions are mentioned or referred to only once in the entire month. The ones recurring more often are listed below.

Mentioned or referred to five times:

Iga lahkumine on raske, iga teelesaatmine kurb 'Every departure is hard, every goodbye is sad' (obituary announcement; e.g., PM May 17th, 2013, p. 22).

Mentioned or referred to four times:

Kontorirott suudab 'An office rat is able [to do]' (advertisement; e.g., PM May 30th, 2013, p. 14).

Mentioned or referred to three times:

Ükski hea inimene ei kao jäädavalt. Ta elab neis, kes teda armastasid 'No one that is a good person disappears forever. He will live on in those people that loved him' (death announcement; e.g., PM May 17th, 2013, p. 22).

Kord köik leiavad oma taeva, sealpool pilvi, valu ja vaeva. . . 'Everyone will find his own heaven, behind clouds, pain, and difficulties ...' (death announcement; e.g., PM May 29th, 2013, p. 29).

Mentioned or referred to two times:

Igal asjal on kaks külge 'Each thing has two sides' (e.g., PM May 31st, 2013, p. 12). Lase oma sisemine . . välja! 'Let your inner . . out!' (e.g., PM May 2nd, 2013, p. 11).

Maraton on elamus! 'The marathon is the happening!' (e.g., PM May 3rd, 2013, p. 17).

Olla vôi mitte olla 'To be or not to be' (e.g., PM May 25th, 2013, p. 1).

Oma kórv on kuninas 'Your own ear is the king' (e.g., TPM May 15th, 2013, p. 8). Poleks taati, ei aitaks ka sada hiirt 'If it was not grandpa even one hundred mice could not help' (e.g., PM May 6th, 2013, p. 13). 
Póhiharidusega riiki ei ehita 'The state is not built with elementary education' (e.g., PM May 16th, 2013, p. 2).

Raha paneb rattad käima 'Money makes the wheels go round' (e.g., PM May 7th, 2013, p. 2).

Reeglid on köigile täitmiseks 'Rules are for everybody' (e.g., PM May 22nd, 2013, p. 1).

Suu teeb suure linna, käed ei tee kärbse pesagi 'A mouth makes a big castle but hands do not make even a fly nest' (e.g., PM May 14th, 2013, p. 12).

Vähem mulli, vähem soola, vähem janu 'Less bubbles, less salt, less thirst' (e.g., PM May 28th, 2013, p. 7).

Üht rä̈gid, teist mottled, kolmandat teed 'You are talking about one thing, you are thinking another thing, and you are doing a third one' (e.g., PM May 10th, 2013, p. 1).

Köik ei ole kuld, mis hiilgab 'All that glitters is not gold' (e.g., PM May 7th, 2013, p. 2).

\section{Finland}

The majority of the proverbs and proverbial expressions were mentioned or referred to only once in the entire month. Those appearing more than five times are listed below.

Mentioned or referred to 128 times:

Suku on pahin 'Family is the worst' (the proverb also appears as Perhe on pahin

'Family is the worst'; ${ }^{30}$ e.g., HS May 1st, 2013, p. C22).

Mentioned or referred to ninety-three times:

Vanha suola janottaa 'Old salt makes one thirsty' (e.g., SSS May 21st, 2013, p. 20). Mentioned or referred to eighteen times:

Älä heitä hanskoja naulaan 'Do not throw your gloves on the hook'; the English equivalent would be 'To throw in the towel' (e.g., HS May 5th, 2013, p. E26).

Mentioned or referred to eleven times:

Mitä välii; Ei mitään välii 'What does it matter; Nothing matters'; the English equivalent could be, for example, 'Big deal' (e.g., HS May 10th, 2013, p. N15). Mentioned or referred to ten times:

Ajattelen, siis olen 'I think, therefore I am'. This was referred to nine times as Piirrän, siis olen 'I draw, so I exist'; translation of Latin Cogito ergo sum (e.g., SSS May 27th, 2013, p. 16).

Mentioned or referred to nine times:

Osua naulan kantaan 'Hit the nail on the head] (e.g., HS May 25th, 2013, p. C25). Älä nuolaise ennen kuin tipahtaa 'Do not lick before dropping'; the English equivalent would be 'Don't count your chickens before they're hatched'. It was

30 Suku is the extended family, and Perhe is the immediate family. 
referred in the shortened form Älä nuolase 'Don't lick' as name of a TV program (e.g., HS May 24th, 2013, p. D4).

Mentioned or referred to six times:

Kell' ei oo heilaa helluntaina, ei oo koko kesänä 'Whoever does not have a sweetheart on Whit Sunday will not have a sweetheart all summer' (e.g., HS May 18th, 2013, p. C27).

Oma koti kullan kallis 'One's own home is precious as gold' (e.g., SSS May 11th, 2013, p. 10).

Yrittänyttä ei laiteta 'The one who is trying to do something won't be slandered' (e.g., SSS May 27th, 2013, p. 16).

\section{Slovenia}

Proverbs are used only thirty-four times in the entire month of May 2013 (1.36 cases per issue), and the only repeated proverbs are two that appeared twice. These two proverbs are also the ones that are often used in everyday communication. Their meaning is well known to most speakers, and so the risk of not understanding the section of the text is minimal. Mentioned or referred to two times:

Ena lastovka še ne prinese pomladi 'One swallow doesn't make the spring' (e.g., DN May 11th, 2013, p. 20).

Ko mačke ni doma, miši plešejo 'When the cat's away, the mice will play' (e.g., DN May 17th, 2013, p. 6).

Other proverbs are mentioned or referred to only once.

Although the usage of proverbs is low, it must be emphasized that the use of metaphorical language is quite high. The text includes many phrasemes and metaphors, but because they are not the subject of this article they are not addressed in greater detail.

\section{PROVERBS IN NEWSPAPER GENRES AND SECTIONS}

Within the context of this study, newspaper genres and sections are understood as a common concept for all three countries, denoting the genres and sections of the text in which the proverbial expression occurs. Observing proverbs in newspaper genres and sections indicates what the text is used for: for example, in articles, news, critics, and comics. In all three language domains, proverbs are most often found in the articles; however in the Finnish newspapers HS and SSS they appear most often in TV programs. On the other hand, proverbs are seldom found in captions or advertising texts.

There are also some general differences between the genres and sections of text in Estonian, Finnish, and Slovenian newspapers. In Estonian newspapers, proverbs in in-text citations are common, in Finnish newspapers proverbs are most often to be found in the names of TV programs, and in Slovenia readers encounter proverbs in opinion pieces or readers' letters to the editor. 
Newspaper genres vary; for example, news appears in a formal text, possibly anonymous (usually produced by a news agency), whereas an "article" is always written by an attributed person. A column is a lighter, informal text. For an opinion piece or letter, the author is not a journalist. A citation is a quote from a specific person, either separately or within an interview. An advertisement is a commercial announcement. A text with a picture is a photo with an accompanying text, a cartoon, or comics. The newspaper section called $\mathrm{TV}$ and radio is mostly program scheduling.

In Slovenian and Estonian newspapers, the majority of proverbs appear in articles. However, they differ in the second-most-frequent section, which is opinion pieces in Slovenia's DN, whereas in Estonia's PM this is news, and in TPM it is citations. In contrast, in Finnish newspapers proverbs are most often found in headlines because they occurred most often as the titles of TV programs. For more details, see the country-specific features presented below.

\section{LOCATION IN THE TEXT}

The location of the proverb or reference to the proverb within a newspaper text includes, for example, various levels of headlines, locations in the text, or use with a picture. Previous studies (see Järv 2009) have pointed out that the impressiveness of a proverb depends on its location within the text. Although there are some inter-country variations, in general the number of headlines is equal to the sum of all other kinds of texts. A closer look shows that locations with references to proverbs are mostly in the text body and headlines (see Table 3).

Table 3. Distribution of proverb occurrence across location of text (in percent)

\begin{tabular}{|c|c|c|c|c|c|c|c|}
\hline & \multicolumn{2}{|c|}{ Estonian } & \multicolumn{3}{|c|}{ Finnish } & \multirow{2}{*}{$\begin{array}{c}\text { Slovenian } \\
\mathrm{DN}\end{array}$} & \multirow[b]{2}{*}{ Total } \\
\hline & $\mathrm{PM}$ & TPM & HS & SSS & PsL & & \\
\hline $\begin{array}{l}\text { Headline (headline, subheadline, } \\
\text { headline of the paragraph) }\end{array}$ & 14.8 & 35.8 & 63.6 & 56.5 & 12.5 & 19.4 & 43.7 \\
\hline $\begin{array}{l}\text { Text (first paragraph, in the text, last } \\
\text { paragraph) }\end{array}$ & 84.6 & 63.0 & 32.3 & 41.3 & 87.5 & 80.6 & 53.9 \\
\hline $\begin{array}{l}\text { With picture (comics, cartoons, text } \\
\text { for photo) }\end{array}$ & 1.2 & 1.2 & 4.1 & 2.1 & 0.0 & 0.0 & 2.5 \\
\hline In $\%$ & 100 & 100 & 100 & 100 & 100 & 100 & 100 \\
\hline Total number of proverbial expressions & 481 & 81 & 560 & 375 & 8 & 36 & 1,541 \\
\hline
\end{tabular}

Unlike in the pilot study, here we were also interested in what part (beginning, middle, or end) of the texts proverbs occurred: the most common were the text and headlines.

If the TV schedule headlines in Finnish newspapers are disregarded, the most common place for proverbs is the text body. The purposes of proverbs are to confirm some previously expressed thought and to stress the findings. With the use of a proverb, the thought 
or opinion expressed received support from the "authority" of common knowledge and rules expressed in proverbs.

The reason why headlines are the most common places for proverbs may be connected with the rhetorical power that proverbs have. The same may account for their use in the first paragraph of text as well as in the concluding sentence. For the latter two cases, there is a crucial distinction in purpose: in the first paragraph, a proverb gives the topic a direction that is further explored; in the concluding sentence, a proverb sums up the topic discussed with the support of authority, common knowledge, and awareness.

\section{SOME FEATURES OF PROVERB USAGE IN NEWSPAPERS}

\section{ESTONIA: PROVERBIAL EXPRESSIONS IN HOROSCOPES IN POSTIMEES, A}

\section{NATIONAL NEWSPAPER}

In Estonian newspapers, proverbial sayings abound in the horoscope section. This is a unique phenomenon compared to Finnish and Slovenian newspapers, and so it was chosen for further inspection. In Estonia, the daily horoscope is an inseparable accessory of any newspaper or news company website; it is usually placed next to other future predictions; for example, the weather forecast. Unlike the weather forecast, with the horoscope it is difficult to judge its accuracy. At the end of every nationwide Postimees miscellany section is a daily horoscope, in which concrete guidelines for the particular day are given for the twelve signs of the zodiac. A weekly horoscope is published at the end of the Saturday supplement, called Postimees Arter. During May 2013, altogether twenty-seven proverbial expressions of folk wisdom were published in horoscopes.

The majority of proverbs in horoscopes concern human-centered abstract concepts such as happiness and health (according to the Matti Kuusi International Type System of Proverbs, D (The world and human life) and G (Social life); Lauhakangas 2001). For example, Ónn ja rahulolu sóltuvad sellest, kuidas enda ümber toimuvat tólgendad 'Happiness and satisfaction depend on how you interpret things that happen around you' (PM May 28th, 2013, p. 17), and Tervis ja ónn on sinu enda teha 'Your health and happiness are in your hands' (PM May 2nd, 2013, p. 22).

In addition to abstract topics, expressions concerning money and fortune are also abundant: Vara ei ole veel köik, kuid ka ilma selleta oleks raske 'Fortune isn't everything, but it is also difficult without it' (PM May 9th, 2013, p. 23) and Tóded, et raha tuleb ja raha läheb. 'You point out that money comes and goes' (PM May 24th, 2013, p. 21). One of the daily horoscope's objectives is to give the day a positive start, even for those that are not having a good time, and therefore aphorisms used are generally optimistic: Väike ebaónnestumine ei ole veel köige lópp 'A little failure isn't the end' (PM May 9th, 2013, p. 23), Raskes hetkes peitub mingi maagilisus 'There is some magic in difficult times' (PM May 15th, 2013, p. 20), Eluväsimusele järgneb uus elurôóm 'After weariness of life comes joy of living' 
(PM May 28th, 2013, p. 17), and Märkad, et kui ühtepidi ei saa, siis teistpidi saab ikka 'You notice that, when you can't go one way, you can go the other' (PM May 10th, 2013, p. 26).

There is also consolation that there are always ups and downs in life: Róóm ja mure käivad käsikäes 'Joy and trouble go hand in hand' (PM May 28th, 2013, p. 17) and Sinu elus on korraga nii sóda kui ka rahu 'In your life there is war and peace at once' (PM May 30th, 2013, p. 19).

There are also hints at proverbs and two direct referrals to traditional proverbs: Juba vanasóna ütleb, et raha paneb rattad käima 'Even the proverb says that money makes the wheels go round' (PM May 8th, 2014, p. 21) and Meenutad vanasóna kulla hiilgamisest 'You remember a proverb about the shining of gold' (PM May 23rd, 2013, p. 17) (a reference to the traditional proverb Köik ei ole kuld, mis hiilgab 'All that glitters is not gold').

In these cases, a proverb is used as a helping hand, most often in the formulation: "as the proverb says," "even a saying tells us," "you know the saying." František Čermak (2004) has postulated that speakers may feel it necessary to introduce whatever they are going to say next by a word or combination of words. He calls the units used for this purpose introducers of proverbs or other idioms. As mentioned above, there are two cases of this kind of target-orientated use of expressions.

A cultural explanation of the presence of proverbs in the horoscopes in national daily newspapers in Estonia refers to the great popularity of modern astrology already during the time when Estonia was part of the Soviet Union and the fact that astrology continues to be one of the most common folk beliefs in Estonia (Kasak 1996). ${ }^{31}$ One can assume that the general characteristic of the entire proverb genre seems suitable for using proverbial expressions in horoscopes, dividing humankind into twelve distinct groups.

\section{FINLAND: PROVERBIAL EXPRESSIONS IN THE NAMES OF TV PROGRAMS IN} HELSINGIN SANOMAT (A NATIONAL NEWSPAPER) AND SALON SEUDUN SANOMAT

\section{(A REGIONAL NEWSPAPER)}

Proverbs are a part of the vernacular that people are familiar with. Both newspaper and television are in daily use as instruments of communication. Proverbs are indisputable ways to express ideas for newspaper readers and TV viewers. Proverbs derive their informative power from their brevity and briskness as well as their modifiability for multiple purposes.

Roughly half of all the proverbial expressions in the three Finnish newspapers studied are related to TV and radio programs. This is in line with the results of the pilot study in 2012 (Granbom-Herranen 2013). This study seems to indicate that there might be something

31 According to the data of the 2011 Population and Housing Census, 29\% of the Estonian population age fifteen and older are affiliated with a particular religion and $54 \%$ of the population fifteen and older does not feel an affiliation to any religion (PHC 2011, <http://www.stat.ee/65352?parent_ $\mathrm{id}=39113>$ ). At the same time, in Estonia nowadays, new spirituality is widespread and contemporary print media are important carriers of spiritual and esoteric ideas. Annual horoscopes tend to nearly double the print-run of newspapers (Uibu and Saluste 2013: 92). 
that makes proverbial expressions in TV programs a Finnish phenomenon. The names of the programs are given by the broadcasting companies and printed in newspapers. Thus this phenomenon is not something unique to any newspaper. Therefore the section called "TV \& radio" was chosen for further inspection. Because the radio programs feature only a couple of proverbial expressions (only four proverbial expressions, occurring a total of ten times), radio was excluded from further inspection. Of the Finnish newspapers (HS, SSS, and PsL), TV programs were included in two. Both HS and SSS publish daily TV schedules for the most popular channels). In both HS and SSS, proverbs occur most often in headlines and sub-headlines. The names of the TV programs have to be both familiar and at the same time they are supposed to rouse interest because the programs' ratings are important for marketing. In these two newspapers in total, 412 proverbs and references to proverbs (of which 323 are single occurrences) are related to TV. This accounts for more than two out of five proverbial expressions in these newspapers because the total number of proverbial expressions in three Finnish newspapers was 958.

The occurrence of proverbial expressions in the names of the TV programs could be related to the history of TV in Finland. Finnish proverbs have always been understood as a part of Finnish heritage, and from the beginning TV has had a position as a recognized media and status symbol. Television broadcasts started in Finland in the mid-1950s, whereas in many European countries and in the United States they had begun in the 1930s. ${ }^{32}$ Still in the 1950s, the state-owned broadcasting company considered television most suitable for rich states and densely populated areas. ${ }^{33}$ However, by the 1970 s near every Finnish household had at least one television set ${ }^{34}$ and in 2013 the number of television sets in Finland was 4.4 million whereas the total population of Finland was approximately 5.5 million. Today $94 \%$ of people still use a TV rather than a computer or smart phone to follow the media. ${ }^{35}$ From 1958 to 2013, all owners of TV sets had to pay a television license fee to the state (similarly for radios from 1927 to 1976), today included as part of annual household taxes. The average person watches three hours of TV daily, seeing approximately thirty-two commercials and, because the majority of the programs are viewed as direct broadcasts, even the title of a program is important. ${ }^{36}$

From the viewpoint of a reader, if a person read all the issues of the newspapers Helsingin Sanomat and Salon Seudun Sanomat in May $2013^{37}$ he or she encountered proverbs and proverbial expressions in TV programs more than four hundred times. This is more than

$32<$ http://www.kolumbus.fi/webweaver/tv.html> (accessed October 9th, 2014).

$33<$ http://sik.ayy.fi/oldwww/sik75/muut/tv-frame.htm> (accessed October 9th, 2014).

$34<$ http://fi.wikipedia.org/wiki/Televisio > (accessed October 9th, 2014).

$35<$ http://vrk.fi/default.aspx?site=4> (accessed October 11th, 2014).

36 Finnpanel: <http://www.finnpanel.fi/tulokset/tv/kk/ohjryh/2013/10/kotimfiktiot.html> (accessed October 9th, 2014).

37 In Finland it is quite common to follow more than one newspaper daily, most often one national paper and one regional one. 
ten times every day on average. Of course, in actual fact both HS and SSS also have a weekly preview collage of TV programs of the upcoming week besides the daily program.

The top four Finnish proverbs in TV programs in May 2013 were the following:

Suku on pahin 'Family is the worst'; the proverb is the basic form for Perhe on pahin 'Family is the worst'. This occurred or was referred to 128 times (a total of 128 in newspapers). Perhe on pahin is a TV program with the original title All in the Family (e.g., HS May 1st, 2013, p. C22).

Vanha suola janottaa 'Old salt makes one thirsty' is a well-known proverb. It occurred ninety-two times as the name of a TV program (a total of ninety-three times in newspapers). Vanha suola janottaa is a TV program with the original title As Time Goes By (e.g., SSS May 21st, 2013, p. 20).

Ajattelen, siis olen 'I think, therefore I am' was referred to nine times as Piirrän, siis olen (a total of ten in newspapers). It is a translation of the Latin proverb Cogito ergo sum (e.g., HS May 23rd, 2013, p. C22).

Älä nuolaise ennen kuin tipahtaa 'Do not lick before dropping' was referred to seven times in the shortened form Älä nuolase 'Don't lick' as the name of a TV program (e.g., HS May 24th, 2013, p. D4); a total of nine in all newspapers, once used as is and once referring to a dog: . . ja alkaa seurata niitä kuono lattiassa. Kielikin suusta tipahtaa, vaan . . . . . . and starts to follow them with the nose on the floor. Even the tongue falls out of the mouth but ... (HS May 20th, 2013, p. A16). An equivalent proverb is "Don't count your chickens before they hatch."

\section{SLOVENIA: PROVERBIAL EXPRESSIONS IN OPINION PIECES IN DNEVNIK, A NATIONAL NEWSPAPER}

Opinion pieces are letters and comments from readers to the editor on current issues, usually written by non-journalists. In most cases, opinion pieces criticize something and people use the same language they use in daily life. Opinion pieces are the only part of a newspaper that can show active knowledge of proverbs among common people. Proverbs are used for expressing thoughts and summing up the point of the text.

During May 2013, twelve different proverbs occur in opinions. Three of them are repeated twice within a single text: first as the title, and then as part of the text:

The proverbs manj je labko več 'less can be more' and laž ima kratke noge 'a lie has short legs' were modified into: zakaj je manj labko več 'why less can be more' (DN May 4th, 2013, p. 55) and Laž ima kratke noge in dolg nos 'a lie has short legs and a long nose' (DN May 15th, 2013, p. 13) and were repeated in the first paragraph of the text; the proverb neumnost ne pozna meja 'stupidity has no bounds' was repeated as the last, concluding sentence of the entire text (DN May 18th, 2013, p. 56).

Exclusively proverbs are used in titles: če je vojna, je vojna za vse 'if there is war, it is war for all' (DN May 3rd, 2013, p. 28), riba smrdi pri glavi 'a fish smells from its head' (DN May 4th, 2013, p. 55), mislim, torej sem 'I think, therefore I am', and ko mačke ni doma, 
miši plešejo 'when the cat's away, the mice will play'. The proverbs are all slightly modified in order to reflect the topic (mislim, torej sem > čutim, torej sem 'I feel, therefore I am' (DN May 7th, 2013, p. 28) and ko mačke ni doma, miši plešejo > Ko mačke (Camerona) ni doma, miši (torijski poslanci) kolo plešejo) 'When the cat's away, the mice dance > When the cat (Cameron) is away, the mice (Tory members) dance the circle dance' (DN May 14th, 2013, p. 40). By using a proverb in the title, the author gives an ironic cast to the topic at hand-the use of a "traditional truth," which in most cases criticizes, indicates that history is repeating itself in slightly different forms.

Proverbs and references to them in the text of letters to the editor in include the following:

Kdor dela, dela napake $>$ Kdor dela, dela tudi napake 'whoever works also makes mistakes' (DN May 11th, 2013, p. 56).

Država da, država vzame > Res drži rek: "Država da, država vzame” 'the saying: "the state gives, the state takes away” is true' (DN May 15th, 2013, p. 15).

Neumnost ne pozna meja > Bo že držalo, človeška neumnost ne pozna meja 'It holds that human stupidity has no limits' (DN May 18th, 2013, p. 56).

Strup je $v$ majhnih flaškah 'Poison comes in small bottles.' This proverb is used as a sentence with no modifications (DN May 25th, 2013, p. 56).

Tresla se je gora, rodila se je miš > Stranke in združenja, ki nastajajo po protestih, se rojevajo po principu "tresla se je gora, rodila se je mis"' The mountain was shaking, but only a mouse was born' > 'Parties and associations that arise after protests are established by the principle "the mountain was shaking, but only a mouse was born." (DN May 25th, 2013, p. 25).

Dan se po jutru pozna > Če se po jutru dan pozna, nas čakajo, tako upam, še številna prijetna presenečenja 'If the day shows after morning, we will get, at least I hope so, many more surprises' (DN May 29th, 2013, p. 32).

Bolje je biti prvi na vasi kot zadnji v mestu > . . ampak takrat smo bili vsaj prvi kmet na vasi, zdaj pa smo zadnji mešćan 'better to be the first in the village than the last in the city, but then we were all at least the first farmer in the village, but now we are the last bourgeois' (DN May 31st, 2013, p. 1).

All of the proverbs in opinion sections are commonly known proverbial expressions, quite often used in everyday language. The authors refer to these as "old proverbs" or "Slovenian proverbs" and "sayings" (which are proven to hold the truth), even though they are obviously writing down a proverb. This case confirms that emic language uses proverbs and sayings as synonyms, and the distinction between them is not clear as in etic language. People use them as a ready-made sentence convenient for the context they have. 


\section{CONCLUSIONS}

The aim of this article was to make some observations of proverbs and proverbial expressions in contemporary newspaper contexts and in everyday use. The idea of following proverbs in newspapers for one month was to show different usages of proverbs and references to them in newspaper contexts. The study included six newspapers: two from Estonia, three from Finland, and one from Slovenia. In every country, at least one newspaper was a national daily. The first challenge in conducting this research was the concept of proverb. In defining concepts linked to proverbs, we encountered the problem of emic definitions and the paradox of modern proverbs. In addition, it emerged that the folklore traditions of all three countries differ in how traditional and modern proverbs are defined. Finding common ground in references to traditional proverbs was easier because, once the basic concept is defined, references to it are quite undemanding to identify. It is possible that we will also find references to modern proverbs in the near future. The question is to what extent a proverb is allowed to change before it ceases being a recognized proverb. Proverbs are in live use so long as they are referred to, but at what point is an utterance no longer a proverb? Proverbs in Estonian, Finnish, and Slovenian newspapers are just unique cases, but the same question can be posed everywhere and in all circumstances: what can be expected to survive when the environment changes but the form of speech remains? It may be as Järv (2009: 266) concluded: "What has remained unchanged, however, is the use of proverbs in newspapers, by politicians, and by society at large." Having taken this into consideration, each researcher applied the definition used in her cultural language area. This means that comparisons are to be understood suggestively. Because language barriers keep us from cross-validating each other's work, we have concluded that each of us is responsible for the material in her own language and within her own culture. In any case, the material will be used for single-culture-centered reflections in future articles.

Inspection of the material shows some visible cultural similarities in the use of proverbs in newspapers in Estonia, Finland, and Slovenia. Many proverbs have international parallels, but, in order to understand them within a specific context, the specific local and global sociocultural context must be known. Even if living conditions and everyday practices have changed over time, traditional proverbs are also alive in contemporary language and they have a place as part of modern communication.

The number of proverbs per page was the highest in Estonia's Postimees, whereas Slovenia's Dnevnik had the fewest proverbs. This study does not indicated the reason for this; this issue could be examined in another article. In a relative sense, both Estonian and Slovenian newspapers have a higher percentage of modern proverbs, whereas Finnish newspapers' references to traditional proverbs seem to be the most frequent form of proverb usage. The conclusion is that in Finnish traditional proverbs are still in use and quite well known because, in order to refer to proverbs, they have to be known. 
When looking at newspaper genres, at first glance it is obvious that broadcast programs are leading the use of proverbs. However, a second glance indicates that this is mostly the case in the Finnish newspapers.

Among all the texts, proverbs are most often found in articles, and writers of opinion pieces also express themselves with proverbs. Using proverbs in articles and opinion pieces confirms the active role of proverbs in these three languages. Proverbs are truly alive and in use. This verifies the hypothesis that proverbs are still a rhetorical element in the everyday language used in newspapers. The working hypothesis concerning new proverbial expressions in newspaper texts is also confirmed. In all three countries, proverbial expressions from various eras are used in newspapers.

To sum up, proverbs are used as rhetorical tools, and this is why readers often encounter them when reading daily newspapers. Nevertheless, it is obvious that the Slovenian newspaper included many fewer proverbs than Estonian and Finnish papers. This could be a new question to study in the future.

In all three countries, it seems that, if a text is intended as informative, journalists avoid utterances like proverbs to avoid misunderstandings: in informative pieces, the text must be short and clear. However, in interpretative articles, such as columns and in short letters to the editor, proverbs can be used quite freely. Opinion pieces are an informal genre, and writers use the everyday language they are familiar with. It could be assumed that modern proverbs find their way first of all into sections that are most up to date. The proverbial structure is one of the user's acquired cultural experiences, which they fill with new topics. Proverbs have always been connected with telling stories, discussion, and metatexts. In newspapers, the author of the text might be important. Unlike in Estonian and Finnish newspapers, in Slovenian newspaper it is notable that some authors used proverbs on a more regular basis.

The project found both similarities and special features regarding proverbs in newspapers in Estonian, Finnish, and Slovenian. Proverbs are more commonly used in some places within a newspaper text, although texts are both culture- and language-specific and are connected with the publishers of newspapers. New proverbial expressions are used in newspaper texts.

Proverbs are no longer used only in a fixed form. Proverbs are often changed to fit the context grammatically or even lexically, but they still retain their meaning. In these newspaper texts, if proverbs are used in their dictionary form (a fixed form), they are also usually preceded by text introducers that are statements, such as "as the (old) proverb says" or "old wisdom says." Proverbs are often modified to reflect the context. 


\section{REFERENCES}

Arora, Shirley L. 1994. The Perception of Proverbiality. In: Wolfgang Mieder (ed.), Wise Words: Essays on the Proverb. New York: Garland Publishing, 3-29.

Babič, Saša. 2010. Sodobne modifikacije pregovorov, frazemov in drugih folklornih obrazcev [Contemporary Modifications of Proverbs, Sayings and Other Small Folklore Forms]. Slavica Slovaca 45 (2): 154-161.

Babič, Saša. 2013. The Use of Proverbs in Slovene Language (The Newspaper Project). In: Rui J. B. Soares and Outi Lauhakangas (eds.), 6th Interdisciplinary Colloquium on Proverbs $-6^{\circ}$ Colóquio Interdisciplinar sobre Provérbios: Proceedings. Tavira: IAP-AIP, 426-435.

Babič, Saša. 2014. Proverbs in a Folklore Moment. In: Vida Jesenšek and Dmitrij Dobrovol'skij (eds.), Phraseologie und Kultur = Phraseology and culture. Maribor: Filozofska fakulteta (Zora; 96), 151-158.

Babič, Saša. 2015. Beseda ni konj: Estetska struktura slovenskih folklornih obrazcev [A Word is Not a Horse: The Aesthetic Structure of Slovenian Short Folklore Forms]. Ljubljana: Založba ZRC.

Ben-Amos, Dan. 1976. Analytic Categories and Ethnic Genres. In: Dan Ben-Amos (ed.), Folklore Genres. Austin: University of Texas Press (American Folklore Society, Bibliographical and Special Series; 26), 215-242.

Boškovič-Stulli, Maja. 1980. Proverbs and Proverbial Expressions in a Zagreb Newspaper. In: N. Burlakoff and C. Lindahl (eds.), Folklore on Two Continents: Essays in Honor of Linda Degh. Bloomington, IN: Trickster Press, 180-186.

Briggs, Charles L. 1988. Competence in Performance. Philadelphia: University of Pennsylvania Press.

Carson Williams, Fionnuala. 2009. Proverbial Expressions, the Local Press and the Current "Troubles" in Northern Ireland. In: Mare Köiva (ed.), Media and Folklore: Contemporary Folklore IV. Tartu: ELM Scholarly Press, 216-238. http://www.folklore.ee/rl/pubte/ee/cf/cf4/CF4_Williams.pdf

Čermák, František. 2004. Text Introducers of Proverbs and Other Idioms. In: C. Földes and Jan Wirrer (eds.), Phraseologismen als Gegenstand sprach- und kulturwissenschaftlicher Forschung. Baltmannsweile: Schneider Verlag Hohengren, 27-46.

Chlosta, Christoph (et al., eds). 1993. Das Sprichwort in der überregionalen Tagespresse: Eine systematische Analyse zum Vorkommen von Sprichwörtern in den Tageszeitungen ,Die Welt', ,Frankfurter Allgemeine Zeitung und ,Süddeutsche Zeitung. Wirkendes Wort: Deutsche Sprache und Literatur in Forschung und Lehre 43 (3): 671-695.

Čubelić, Tvrtko. 1988. Povijest i historija usmene narodne književnosti: historijske i literarno-teorijske osnove te genološki aspekti - analitičko-sintetički pogledi [History of Verbal Folklore: Historical and Literal Theory Basis and Gnoseological Aspects - Analytically Syntactical News]. Zagreb.

Dundes, Alan. 1965. The Study of Folklore. Berkeley, CA: University of California at Berkeley.

Eesti vanasõnad [Estonian proverbs.] I-IV. 1980-1988. Eds. Arvo Krikmann and Ingrid Sarv. Tallinn: Eesti Raamat (Monumenta Estoniae Antiquae III. Proverbia Estonica I-IV).

Elo, Satu and Helvi Kyngäs. 2008. The Qualitative Content Analysis Process. Journal of Advanced Nursing 62 (1): 107-115. http://www.brown.uk.com/teaching/HEST5001/elo.pdf, accessed March 15th, 2015.

Ferretti, Todd R., Christopher A. Schwint and Albert N. Katz. 2007. Electrophysiological and Behavioral Measures of the Influence of Literal and Figurative Contextual Constraints on Proverb Comprehension. Brain and Language 101 (1):38-49. http://ac.els-dn.com/S0093934X06002422/1-s2.0-S0093934 X06002422-main.pdf?_tid=9602b4513ecc912233c1bb6b5cedccc5\&acdnat $=1334732314$ _6f0030 b373587db57d6164f321d725db, accessed April 18th, 2012. 
Granbom-Herranen, Liisa. 2008. Sananlaskut kasvatuspuheessa-perinnettä, kasvatusta, indoktrinaatiota? [Proverbs in Pedagogical Discourse: Tradition, Upbringing, Indoctrination?]. Jyväskylä Studies in Education, Psychology and Social Research 329: 278-285. http://urn.fi/URN:ISBN:978-951-39-3111-7, accessed March 15th, 2015.

Granbom-Herranen, Liisa. 2010a. Menetelmät monitieteellisen tutkimuksen haasteena [Multidisciplinary Research Is a Challenge for Research Methods]. Elore 17 (2): 68-78. http://www.elore.fi/arkisto /2_10/herranen_2_10.pdf, accessed March 15th, 2015.

Granbom-Herranen, Liisa. 2010b. Is a Proverb Always a Proverb? In: Rui J. B. Soares and Outi Lauhakangas (eds.), 3rd Interdisciplinary Colloquium on Proverbs, Proceedings. Tavira: IAP-AIP, 215-221.

Granbom-Herranen, Liisa. 2013. "Newspapers Are the Schoolmasters of the Common People" - Some Paremiological Notes on Proverbs in a Finnish Newspaper. In: Rui J. B. Soares and Outi Lauhakangas (eds.), 6th Interdisciplinary Colloquium on Proverbs $-6^{\circ}$ Colóquio Interdisciplinar sobre Provérbios, Proceedings. Tavira: IAP-AIP, 315-328.

Granbom-Herranen, Liisa. 2014a. SMS-Messages - Context for Traditional and Modern Proverbs. In: Vida Jesenšek and Dmitrij Dobrovol'skij (eds.), Phraseologie und Kultur = Phraseology and culture. Maribor: Filozofska fakulteta, (Zora; 96), 545-559.

Granbom-Herranen, Liisa. 2014b. Beyond Understanding: How Proverbs Violate Grice’s Cooperative Principle. In: Anneli Baran, Liisi Laineste and Piret Voolaid (eds.), Scala Naturae: Festschrift in Honour of Arvo Krikmann. Tartu: ELM Scholarly Press, 107-120.

Grice, H. P. 1975. Logic and Conversation. In: Peter Cole \& Jerry L. Morgan (eds.), Syntax and Semantics 3: Speech Acts. New York: Academic Press, 41-58.

Headland, Thomas N., Kenneth L. Pike and Marvin Harris (eds.). 1990. Emics and Etics: The Insider/ Outsider Debate (Frontiers of Anthropology; 7). Newbury Park, CA: Sage.

Honko, Lauri. 1989. Folkloristic Theories of Genre. In: Anna-Leena Siikala (ed.), Studies in Oral Narrative. Helsinki: Suomalaisen Kirjallisuuden Seura (Studia Fennica; 33), 13-28.

Järv, Risto. 1999. Is Providing Proverbs a Tough Job?: References to Proverbs in Newspaper Texts. Folklore 10: 77-107. http://folklore.ee/folklore/vol10/pdf/rjrv.pdf, accessed March 15, 2015. doi:10.7592/ FEJF1999.10.rjrv

Järv, Risto. 2009. Aren't Proverbs There for the Taking? Media \& Folklore: Contemporary Folklore 4: 239-268. http://www.folklore.ee/rl/pubte/ee/cf/cf4/CF4_Jarv.pdf, accessed March 15th, 2015.

Kasak, Enn. 1996. Back to the Past: Some Aspects of the History of Astrology in Estonia. In: Mare Kõiva (ed.), Contemporary Folklore: Changing World View and Tradition. Tartu: Institute of Estonian Language \& Estonian Museum of Literature, 234-239. http://www.folklore.ee/rl/pubte/ee/cf/ cf/17.html, accessed March 15th, 2015.

Kocbek, Fran and Ivan Šašelj. 1934. Slovenski pregovori, prilike in reki [Slovenian Proverbs, Parables and Sayings]. Celje: Družba sv. Mohorja.

Krikmann, Arvo. 1985. Vanasõnaparoodiatest [On Parodies of Proverbs]. Keel ja Kirjandus 8: 474-483.

Krikmann, Arvo. 1997. Sissevaateid folkloori lühivormidesse [Insights into Short Forms of Folklore]. Tartu: Tartu Ülikooli Kirjastus. http://www.folklore.ee/ kriku/PARINTRO/Parintro.pdf

Krikmann, Arvo. 2005. Delfi - peldikusein või aardelaegas [Comments at the Internet Portal Delfi - Toilet Wall or Treasure Box?]. www.folklore.ee/Haldjas10/ppts/KrikuDelfi.ppt, accessed March 15th, 2015.

Kuusi, Matti (ed.). 1990 (1953). Vanhan kansan sananlaskuviisaus [The Wisdom in Proverbs of the Ancient Folk]. Helsinki: WSOY. 
Lauhakangas, Outi. 2001. The Matti Kuusi International Type System of Proverbs. Helsinki: Suomalainen Tiedeakatemia (FF Communications; 275).

Lauhakangas, Outi. 2013. Proverbs, Fragments and Modifications of Proverbs in the Most Widely Read Finnish Newspaper (The Newspaper Project). In: Rui J. B. Soares and Outi Lauhakangas (eds.), 6th Colóquio Interdisciplinar sobre Proverbios - 6th Interdisciplinary Colloquium on Proverbs: Proceedings. Tavira: IAP-AIP, 421-440.

Laukkanen, Kari and Pekka Hakamies (eds.). 1997 (1978). Sananlaskut [Proverbs]. Helsinki: SKS.

Litovkina, Anna and Wolfgang Mieder. 2006. Old Proverbs Never Die, They Just Diversify: A Collection of Anti-Proverbs. Burlington: The University of Vermont.

Lüthi, Max. 1970. Das Sprichwort in der Zeitung. Proverbium 15: 495-497.

Mieder, Wolfgang. 1973. Verwendungsmöglichkeiten und Funktionswerte des Sprichwortes in der Wochenzeitung (Untersuchung der Zeit für das Jahr 1971). Muttersprache 83: 89-119.

Mieder, Wolfgang. 1993. Proverbs Are Never Out of Season: Popular Wisdom in the Modern Age. Oxford: Oxford University Press.

Mieder, Wolfgang. 2008. "Proverbs Speak Louder Than Words": Folk Wisdom in Art, Culture, Folklore, History, Literature and Mass Media. New York: Peter Lang.

Mieder, Wolfgang. 2014. Futuristic Paremiography and Paremiology. Folklore Fellows' Network 44: 13-17. http://www.folklorefellows.fi/wordpress/wp-content/uploads/FFNetwork_44.pdf, accessed March 15th, 2015.

Nirvi, R. E. and Lauri Hakulinen (eds.). 1953 (1948). Suomen kansan sananparsikirja [Book of Finnish Proverbs]. Porvoo: WSOY.

Norrick, Neal R. 1985. How Proverbs Mean: Semantic Studies in English Proverbs. Berlin: Mouton (Trends in Linguistics, Studies and Monographs; 27).

Pilz, Klaus Dieter. 1991. Phraseologie in der (regionalen) Tageszeitung am Beispiel einer Ausgabe der Westdeutschen Allgemeinen Zeitung (=WAZ) vom Samstag / Montag, 30. Dez. 1989 / 1. Jan. 1990. In: Christine Palm (ed.), Europhras 90: Akten der internationalen Tagung zur germanistischen Phraseologieforschung. Uppsala: Acta Universitatis Upsaliensis, 181-209.

Seitel, Peter. 1994. Proverbs: A Social Use of Metaphor. In: Wolfgang Mieder andAlan Dundes (eds.), The Wisdom of Many. Madison: University of Wisconsin Press, 122-139.

Taylor, Archer. 1931. The Proverb. Cambridge, MA: Harvard University Press.

Uibu, Marko and Marju Saluste. 2013. Lugejate virtuaalne kogukond: Kirjandus ja ajakirjandus vaimsete-esoteeriliste ideede kandja ja levitajana [The Virtual Community of Readers: The Dissemination of Spiritual-Esoteric Ideas]. In: Marko Uibu (ed.), Mitut usku Eesti III: Valik usundiloolisi uurimusi: uue vaimsuse eri. Tartu: Tartu Ülikooli Kirjastus, 79-106.

Urbas, Wilhelm. 1869. O pregovorih in prilikah sosebno slovenskih [About Proverbs and Parables, Especially Slovenian]. Jahresbericht der K.K. Ober-Realschule in Goerz 9: 5-33.

Voolaid, Piret. 2012. In graffiti veritas: A Paremic Glance at Graffiti in Tartu. In: Liisi Laineste, Dorota Brzozowska and Władysław Chlopicky (eds.), Estonia and Poland: Creativity and Change in Cultural Communication: Vol. 1: Jokes and Humour. Tartu: ELM Scholarly Press, 237-268. http:// www.folklore.ee/pubte/eraamat/eestipoola/, accessed March 15th, 2015. doi:10.7592/EP.1.voolaid

Voolaid, Piret. 2013. On Paremiological Findings in the Estonian Daily Newspaper Postimees (Newspaper Project). In: Rui J. B. Soares and Outi Lauhakangas (eds.), 6th Interdisciplinary Colloquium on Proverbs $-6^{\circ}$ Colóquio Interdisciplinar sobre Provérbios, Proceedings. Tavira: IAP-AIP, 291-303.

Vygotski, Lev. 1967. Thought and Language, Cambridge, MA: The MIT Press. 


\section{PREGOVORNI IZRAZI V ČASOPISJU RAZISKAVA ESTONSKIH, FINSKIH IN SLOVENSKIH ČASOPISOV}

$Z$ raziskavo rabe pregovornih oblik v časopisju smo začeli leta 2011 na konferenci Colloquium on Proverbs na Portugalskem. Namen je bil predvsem pregledati ćasopisje s paremiološkega vidika. V pilotni raziskavi smo pregledali izbrano časopisje v enem tednu v maju 2012, nato pa se je nadaljevala $v$ pričujoči raziskavi, kjer smo en mesec opazovale pregovore in pregovorne izraze $v$ sodobnih časopisih kot zglede vsakdanje rabe. Vzorčno smo pregledale šest časopisov, ki so izhajali maja 2013: dva estonska (Postimees in Tartu Postimees), trije finski (Helsingin Sanomat, Salon Seudun Sanomat in Perniönseudun Lehti) in en slovenski časopis (Dnevnik). Za vsako državo je bil pregledan en nacionalni dnevnik. Namen je bil predvsem ugotoviti, kako se pregovori in pregovorne oblike pojavljajo v časopisju v treh jezikih in deželah, kateri pregovori se pojavljajo v časopisju, $v$ katerih časopisnih žanrih so uporabljeni, $v$ katerem delu besedila se uporabljajo pogosteje in kakšne so besedilne prilagoditve in modifikacije pregovorov.

Za analizo gradiva so bili najprej pregledani kriteriji za ločevanje tradicionalnih in sodobnih/ novih pregovorov v vseh treh državah ter ugotovitve, do katere mere je pregovor lahko spremenjen, da še spada med tradicionalne pregovore. Čeprav so se življenjske razmere vadnjih sto letih precej spremenile, so tradicionalni pregovori $v$ sodobnem jeziku še vedno zelo živi in imajo posebno mesto $v$ sodobni komunikaciji, ne glede na to, ali so navedeni $v$ tradicionalni obliki ali pa so zgolj referenca na tradicionalno obliko (kar pomeni, da mora bralec tradicionalni pregovor poznati). Hkrati pa proces nastajanja novih pregovorov stalno poteka, pa čeprav se zdi, da neopazno.

Kvantitativni vidik raziskave je pokazal, da je bilo število pregovorov na stran najvišje v estonskem časopisu Postimees, medtem ko je bilo v slovenskem časopisu Dnevnik najmanj pregovorov. Raziskava se ni poglabljala v razloge za to, vendar pa bi to lahko bila tema posebnega prispevka. Estonski in slovenski časopisi so imeli največ t. i. sodobnih pregovorov, finsko časopisje pa je imelo največ referenc na tradicionalne pregovore. Ob pregledu časopisnih žanrov se je pokazalo, da so pregovori v estonskem časopisju najpogostejši v horoskopih, v finskem časopisju v televizijskih sporedih (ker so s pregovori poimenovali serije oddaj, ki so se predvajale v tem času), v slovenskem časopisu pa v pismih bralcev in komentarjih. Vvseh treh državah se v novicah, kjer je poudarjeno informativno besedilo, novinarji izogibajo pregovorom, da bi se izognili nesporazumom, hkrati pa so to sestavki, ki morajo biti jasni in jedrnati. Vkolumnah, mnenjih in pismih pa je raba pregovorov pogosta.

Kvalitativni pregled gradiva je pokazal nekatere vidne podobnosti v rabi pregovorov v estonskem, finskem in slovenskem časopisju. Veliko pregovorov ima mednarodne vzporednice, vendar pa je za njihovo razumevanje potrebno poznavanje tako specifičnega lokalnega kot tudi globalnega sociokulturnega konteksta. Vsekakor pregovori niso uporabljeni zgolj kot nespremenljiva oblika; pogosto so spremenjeni slovnično, da ustrezajo sobesedilnemu kontekstu, včasih tudi leksikalno, čeprav še vedno ohranjajo pomen. Pregovori, ki so zapisani v "slovarski obliki", so ponavadi pospremljeni s kazalniki "star pregovor pravi", "kot pravi stara modrost". Pregovori so pogosto modificirani, da $v$ njih lahko odseva kontekst. 
Analiza je potrdila, da so pregovori v časopisju retorično orodje. Hkrati je to dokaz, da so pregovori še zelo živ žanr, saj bi v nasprotnem bili neuporabni kot retorično sredstvo, ker se novinarji ne bi mogli zanesti na razumljivost napisanega.

Dr. Liisa Granbom-Herranen, University of Turku, Finland Dr. Saša Babič, ZRC SAZU Institute of Slovenian Ethnology, Ljubljana, Slovenia

Dr. Piret Voolaid, Estonian Literary Museum, Tartu, Estonia 